\title{
AEROSOL AND DENTISTRY IN COVID ERA
}

\author{
Dr. Lekha A, Dr. S.K. Balaji \\ Department of Periodontology, Sri Ramachandra Faculty of Dental Sciences, \\ Sri Ramachandra Institute of Higher Education and Research, Chennai, Tamilnadu, India.
}

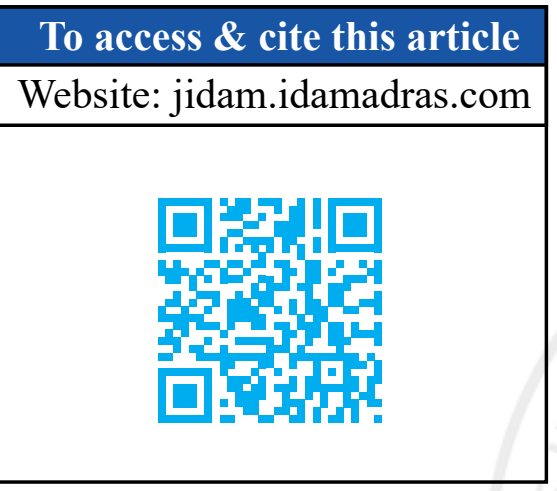

DOI:10.37841/jidam_2020_V7_I3_03

\section{Address for Correspondence:}

Dr. Lekha A, MDS,

Lecturer, Department of Periodontology,

Sri Ramachandra Faculty of Dental

Sciences,

Sri Ramachandra Institute of Higher

Education and Research, Chennai-600

116, Tamilnadu, India.

Email id:drlekha@sriramachandra.edu.in

\section{ABSTRACT}

Aerosol and splatter play a significant role in transmission of infection in a dental set up, which is of great concern for the dentist and the patient. Major source of aerosol in a dental set up is from ultrasonic scalers and rotary instrument which are of primary importance for performing regular dental procedures. Since the aerosolized particles behave in a ballistic manner and can stay suspended in air for a long period of time, the probability of surface contamination and transmission of infection through contact of these contaminated surfaces within dental clinic is extremely high. Presently our anxiety due to possible aerosol contamination has increased multiple folds due to the COVID-19 pandemic crisis. Hence knowing the properties and composition of the aerosol, would give an insight into reducing the microbial load in the aerosol being generated during the regular dental procedures.

KEYWORDS: COVID, Aerosol procedure, Airborne infection

\footnotetext{
Received : : 15.08 .2020

Accepted : : 16.09 .2020

Published : 27.09 .2020
} 


\section{INTRODUCTION:}

The pioneering work done by Micik and colleagues on aerobiology, have defined aerosols as those airborne particles less than $50 \mu \mathrm{m}$ in diameter and if the particles size was larger than $50 \mu \mathrm{m}$ in diameter, it was called as splatter ${ }^{1-5}$. These particles were found to behave in a ballistic manner.

The consensus has been that the major spread of infection in dental clinic is airborne infection due to aerosol that is generated during dental procedures and its potential to enter respiratory passages ${ }^{6,7}$.

These aerosols generated during the dental procedure pose a risk factor for disease transmission among the dentist, the dental team and the patient. The potential source for spread of infection in a dental office can happen either through direct contact with body fluids of an infected patient or through indirect contact with contaminated environmental surfaces or due to airborne particles from the infected patient. ${ }^{8}$

An aerosol cloud is generated during various dental procedures performed using rotary instruments, ultrasonic scalers, air-water syringe and air polishing instruments. The ubiquitous cloud of aerosol comprises of combination of materials originating from the within the oral cavity and from the Dental Unit Waterline (DUWL). The source of infectious contaminants present in the aerosol can be either from the operative site, saliva and respiratory sources. Literature evidence shows that the greatest amount of airborne contamination is generated by the ultrasonic scaler, followed by the air-driven high-speed hand piece, the air polisher and air-water syringe ${ }^{5,9-14}$.

\section{COMPOSITION OF DENTAL AEROSOLS:}

The oral fluids are grossly contaminated with bacteria and viruses from supragingival plaque and also from deep periodontal pockets. Oral cavity being a part of the oro-nasal pharynx complex, harbours microorganisms from the nose, throat and respiratory tract. Dental procedures which generate aerosol, potentially cause airborne contamination with organisms from some or all of these sources. ${ }^{15}$

The composition of dental aerosol varies with operative site and each patient. Hence it is extremely difficult to analyse the aerosol qualitatively and quantitatively. The dental aerosol supposedly comprises of components of saliva, blood, nasopharyngeal secretions, plaque, tooth fragments and dental material used for treatment. Several studies have been done to assess the number of bacteria present and also analysed the blood components present in the dental aerosol ${ }^{16,17}$.

Tuberculosis is considered as an occupational hazard in dentistry, because the most potential threat that can be present in dental aerosol is Mycobacterium tuberculosi ${ }^{18,19}$. Several other pathogenic organisms like the SARS virus, influenza virus, herpes virus, pathogenic Streptococci and Staphylococci are found in the nasopharyngeal secretions and saliva, thereby increasing the risk of spread of infectious disease conditions through dental aerosol .

\section{DROPLETS AND AEROSOLS - ITS SIGNIFICANCE IN DISEASE TRANSMISSION}

Studies have proven that highly virulent pathogens like severe acute respiratory syndromecoronavirus (SARS-CoV) present in aerosol can travel distances greater than six feet ${ }^{20}$. Surfaces contaminated with nosocomial pathogens are potential route of transmission for several infections ${ }^{21}$.

Human corona virus including SARS-CoV and MERS-CoV can undergo onward transmission because of their ability to persist on a surface for a few days, and also due to their ability to remain suspended in human secretions ${ }^{21,22}$. Acquisition of pathogen from contaminated surfaces and if when transferred to the eyes, nose, or mouth can result in transmission of infection ${ }^{21}$. 


\begin{tabular}{|l|l|}
\hline \multicolumn{2}{|l|}{ Disease transmission that occurs through Airborne route via Droplets or Aerosols ${ }^{\mathbf{1 5}}$} \\
\hline DISEASE & METHOD OF TRANSMISSION \\
\hline Pneumonic Plague & $\begin{array}{l}\text { Transmits from one patient to another by inhalation of the causative } \\
\text { bacteria, without contact with the usual insect vector (flea) }\end{array}$ \\
\hline Tuberculosis & $\begin{array}{l}\text { Transmits via Droplet nuclei which is expelled from the patient while } \\
\text { coughing }\end{array}$ \\
\hline Influenza & $\begin{array}{l}\text { Transmission requires direct contact with the patient but can also be } \\
\text { associated with coughing }\end{array}$ \\
\hline $\begin{array}{l}\text { Legionnaires' } \\
\text { Disease }\end{array}$ & $\begin{array}{l}\text { Aerosolization and transmission of Legionella pneumophila can occur } \\
\text { through air conditioning systems and hot tub spas }\end{array}$ \\
\hline $\begin{array}{l}\text { Severe Acute } \\
\text { Respiratory } \\
\text { Syndrome }\end{array}$ & Spread of disease through direct contact and aerosolized droplets \\
\hline
\end{tabular}

\section{NOVEL CORONA VIRUS:}

A pneumonia outbreak with unknown etiology occurred in Wuhan, China by the end of 2019 and this disease condition was named corona virus disease 2019 (COVID-19). An increase in the number of cases reported worldwide prompted the World Health Organization (WHO) to declare the COVID-19 crisis a "Public Health Emergency of International Concern". On 11 March 2020, WHO declared the Novel Coronavirus Disease (COVID-19) outbreak to be a pandemic. The possible routes of this virus transmission are mainly through direct contact and droplet transmission. An exposure to high concentration of aerosol in a relatively closed environment can be considered as one of the potential route of transmission of COVID-19. Since routine dental procedures like scaling generate high concentration of aerosol, the possibility of corona virus transmission in dental setting is relatively high. Hence knowledge on disease transmission through aerosol and its implication in dentistry is very essential, specifically during this pandemic crisis.

\section{METHODS OF REDUCING AIRBORNE CONTAMINATION:}

There is no single step preventive measure available to completely minimize the risk of infection to dental personnel and the patients. Hence it is advisable to follow a multiple layer of preventive measures because a single layer of defense can partially reduce the risk of cross infection. Toreduce the potential danger from dental aerosol, layering of infection control procedures needs to be followed ${ }^{15}$. Thus, the dental team can adopt the following layers of preventive procedures that is necessary to reduce the dental aerosols ${ }^{15}$. Personal protection barriers such as gloves, masks and protective eyewear will serve as a first layer of defense in protecting the dentist and the assistants within the operatory. Routine use of an antiseptic preprocedural mouthwash such as chlorhexidine will serve as a second layer of defense by minimizing the bacterial load in the oral cavity and use of a high-volume evacuator either by an assistant or attached to the instrument will reduce the quantity of aerosol being generated. Installation of devices such as HEPAfilters, can serve as an additional layer of defense in reducing the aerosol contamination within the operating area. The appropriate work practice precautions are achieved by using rubber dams and HVEs, and hence should be followed during dental procedures $^{23}$.

Centre of Disease Control has suggested "Interim Infection Prevention and Control Guidance for Dental Settings during the Coronavirus Disease 2019 Pandemic" 24 . Since the virus has been shown to persist in aerosol for hours and on some surfaces for few days under laboratory conditions, the potential risk of transmission of virus in a dental setting is high. But there are currently no data available to 
assess the risk of Coronavirus disease transmission during dental practice. Hence CDC has developed a framework for healthcare personnel and healthcare systems for delivery of non-emergent care during the COVID-19 pandemic. Thorough assessment of the patient should be carried out prior to providing any dental treatment. It is important to weigh the risk: benefit ratio for both the patient and the Dental Health Care Provider (DHCP) in deferring the treatment.

Availability of adequate Personal Protective Equipment (PPE) and supplies is mandatory to support both the patient and $\mathrm{DHCP}^{24}$. Implementation of tele-dentistry and triage protocols prior to dental treatment should be followed. CDC have also recommended Infection Prevention and Control (IPC) practices when providing dental healthcare for a patient with suspected or confirmed SARS-CoV-2 infection and for routine dental healthcare delivery during the pandemic ${ }^{24}$.

\section{CONCLUSION:}

Considering the high risk of exposure to serious disease conditions through aerosol contamination among dental clinics, it is mandatory to adapt to various protocols which has been laid down to reduce the quantity of aerosol generated during the routine dental procedures and also minimize the risk of exposure to dental health care provider and patients by following strict infection prevention and control measures.

FINANCIAL SUPPORT AND SPONSORSHIP:

Nil

\section{CONFLICTS OF INTEREST:}

There are no conflicts of interest.

\section{REFERENCES:}

1. Abel LC, Miller RL, Micik RE, Ryge G. Studies on dental aerobiology: IV. Bacterial contamination of water delivered by dental units. J Dent Res 1971 Nov;50(6):1567-9.

2. Micik RE, Miller RL, Mazzarella MA, Ryge G. Studies on dental aerobiology: I. Bacterial aerosols generated during dental procedures.
J Dent Res 1969 Jan;48(1):49-56.

3. Miller RL, Micik RE, Abel C, Ryge G. Studies on dental aerobiology: II. Microbial splatter discharged from the oral cavity of dental patients. J Dent Res 1971 May 1;50(3):621-5.

4. Micik RE, Miller RL, Leong AC. Studies ondental aerobiology: III. Efficacy of surgical masks in protecting dental personnel from airborne bacterial particles. J Dent Res 1971 May;50(3):626-30.

5. Miller RL, Micik RE. Air pollution and its control in the dental office. Dent Clin N Amer $1978 \mathrm{Jul} ; 22(3): 453$.

6. Hinds WC. Aerosol technology: Properties, behavior, and measurement of airborne particles. New York: Wiley; 1982:6-8.

7. Cottone JA, Terezhalmy GT, Molinari JA. Practical infection control in dentistry. Baltimore: Williams \& Wilkins 1996:139-40.

8. Garner JS. Guideline for isolation precaution in hospitals. Infection Control \& Hospital Epidemio 1996;17(01):54-80.

9. Bentley CD, Burkhart NW, Crawford JJ. Evaluating splatter and aerosolcontamination during dental procedures. J Amer Dent Assoc 1994 May 1;125(5):579-84.

10. Legnani P, Checchi L, Pelliccioni GA, D'Achille C. Atmospheric contamination during dental procedures. Quint Internat. 1994 Jun 1;25(6).

11. Gross KB, Overman PR, Cobb C, Brockmann S. Aerosol generation by two ultrasonic scalers and one sonic scaler. A comparative study. J Dent Hyg: 1992 Sep;66(7):314-8.

12. Muzzin KB, King TB, Berry CW. Assessing the clinical effectiveness of an aerosol reduction device for the air polisher. J Amer Dent Assoc 1999 Sep 1;130(9):1354-9.

13. Harrel SK. Clinical use of an aerosolreduction device with an ultrasonic scaler. Compendium of continuing education in dentistry (Jamesburg, NJ: 1995). 1996 Dec;17(12):1185-93.

14. Barnes JB, Harrel SK, Rivera-Hidalgo F. Blood contamination of aerosols produced by 
in-vivo use of ultrasonic sealers. J Periodon 1998 Apr;69(4):434-8.

15. Harrel SK, Molinari J.Aerosols and splatter in dentistry: a brief review of the literature and infection control implications. J Amer Dent Assoc 2004 Apr 1;135(4):429-37.

16. King TB, Muzzin KB, Berry CW, Anders LM. The effectiveness of an aerosol reduction device for ultrasonic sealers. J Periodont 1997 Jan;68(1):45-9.

17. Logothetis DD, Gross KB, Eberhart A, Drisko C. Bacterial airborne contamination with an air-polishing device. G Dent 1988 Dec;36(6):496-9.

18. Smith WR, Mason KD, Davies D, Onions JP. Intra-oral and pulmonary tuberculosis following dental treatment. The Lancet 1982 Apr 10;319(8276):842-4.

19. Belting CM, Haberfelde GC, Juhl LK. Spread of organisms from dental air rotor. J Amer Dent Assoc. 1964 May 1;68(5):648-51.

20. Kutter JS, Spronken MI, Fraaij PL, Fouchier RA, Herfst S. Transmission routes of respiratory viruses among humans. Curr Opin Vir 2018 Feb 1;28:142-51.

21. Otter JA, Yezli S, Salkeld JA, French GL. Evidence that contaminated surfaces contribute to the transmission of hospital pathogens and an overview of strategies to address contaminated surfaces in hospital settings. Amer J Inf Cont 2013 May 1;41(5):S6-11.

22. Kramer A, Schwebke I, Kampf G. How long do nosocomial pathogens persist on inanimate surfaces? A systematic review. BMC infectious diseases. 2006 Dec 1;6(1):130.

23. Kohn WG, Collins AS, Cleveland JL, Harte JA, Eklund KJ, Malvitz DM. Guidelines for infection control in dental health-care settings 2003. MMWR Recomm Rep. 2003 Dec 19;52(17):1-61

24. Center for Disease Control and Prevention. Dental Settings. Interim Infection Prevention and Control Guidance for Dental Settings During the COVID-19 Response. 